\title{
FIRE DETECTION BASED ON A SERIES OF THERMAL IMAGES AND POINT MEASUREMENTS: THE CASE STUDY OF COAL-WASTE DUMPS
}

\author{
A. Abramowicz, R. Chybiorz \\ University of Silesia in Katowice, Faculty of Earth Sciences, Department of Fundamental Geology \\ abramowiczanna@gmail.com, ryszard.chybiorz@us.edu.pl
}

Commission I, WG I/10

KEY WORDS: Upper Silesian Coal Basin, coal-waste dump, fires, self-ignition, thermal images

\begin{abstract}
:
The development of mining areas is always associated with a huge amount of unused gangue. It is treated as waste that should be disposed of. Most often it is done by creating waste dumps. Unfortunately, in the case of hard coal, such treatments can be dangerous, because the remaining coal can self-heat, what then leads to ignition and fire. These fires are uncontrolled and significantly affect the environment and the health of residents. Areas at risk of fire should be properly secured and its thermal conditions monitored. There are currently many methods available for measuring temperature. The latest and also the most popular are pyrometric and remote sensing methods. For the purposes of analysis, fieldwork on the selected coal-waste dump in the Upper Silesian Coal Basin was made using pyrometric (point measurements) and remote sensing methods (thermal images). A series of photos and measurements were compared over time and space to catch change trends. Differences in the received data were identified. Studies have shown that using only one method helps identify a fire, but does not provide enough information about its structure. Comprehensive monitoring is the best solution.
\end{abstract}

\section{INTRODUCTION}

The coal mining industry has led to significant devastation of the natural environment in the area of Upper Silesian Coal Basin, Southern Poland (Gawor, 2014). Coal-waste dumps scattered throughout these areas are one of the prominent signs of the mining impact. They are very difficult to recognize, classify and evaluate (Abramowicz, Chybiorz, 2017). Lack of proper protection and care of these objects leads to frequent fires. The fires of waste material are a big threat, which often arises in the dumps by self-ignition or by external factors, including human activities (Drenda et al., 2007). The complex structure of the dumps and the diversity of the stored material make the phenomenon of fire very difficult to predict and uncontrollable that these objects should be constantly monitored.

Remote sensing methods and pyrometric methods are currently the most popular for studying the dumps' thermal state (Wasilewski, Korski, 2009; Korski, 2010; Syed et al., 2018). Both types require different technology and equipment. They also differ in the required conditions, time, accuracy and type of measurements. Both methods have numerous advantages, but unfortunately, none of them is perfect. Numerous limitations pose a question: which methods work better for detecting fires of the coal-waste dumps?

The aim of the study was to compare pyrometric and remote sensing methods using the example of a selected object burning coal-waste dump in Ruda Śląska, Upper Silesian Coal Basin, Poland (Figure 1A; Jonczy, Gawor, 2017). The dump was created in the $90 \mathrm{~s}$ of the 20 th century when the waste material from the Wawel coal mine was stored in the place of the former Bielszowice brickyard. In 1995, the stored material began to burn (Laczny et al., 2012) and the fire continues to this day. Currently, the area is divided into two sections - one of them is classified as post-industrial area, and another as a park and recreation area. Despite the high risk, the object is surrounded by commercial, residential and public utility buildings.

\section{METHODS}

On the selected coal-waste dump, field research works were carried out consisting of a series of measurements using a handheld thermal camera, thermal camera mounted on the drone and a pyrometer with a probe. In this way, the thermovision (aerial and terrestrial) and pyrometric (terrestrial and underground) methods were tested. The fieldwork was repeated with an interval of seven months. Recorded data from the air, ground and underground measurements have been collected, processed and compared in time and space with each other and with archive materials.

\subsection{Thermal IR images}

Thermal infrared (IR) photos are currently the fastest method of obtaining reliable data on the thermal state of selected objects (Wasilewski, Choroba, 2011). Depending on the selection of equipment, it is possible to take such pictures in different field conditions. The small dimensions of today's thermal cameras allow for easy transport and installation on drones, which allows taking pictures from the air. Unfortunately, the thermal IR camera is very susceptible to weather conditions, so to obtain reliable data it is necessary to properly adjust the time of measurements. The most important restrictions include lack of rainfall and drizzle, sunlight, strong wind, and air pollution. Performing fieldwork in inappropriate conditions may result in large errors in the received data or the complete inability to collect them (wind, rain or excessive sunlight can completely interfere with the equipment).

For the purposes of the research, a series of thermal photos were taken from the air and from the ground. Professional thermal IR 
cameras from the FLIR series were used for both methods. Taking into account all the constraints, using the FLIR Vue Pro 336 thermal imaging camera (spectral range: $7.5-13.5 \mu \mathrm{m}$ ) on the drone DJI S900, an air raid covering the whole area of the dump (about 9 ha) was carried out. Pictures were taken before sunrise on a cloudless day from a height of $50 \mathrm{~m}$ with GSD $20 \mathrm{~cm} /$ pixel. Pictures have been properly mosaic and processed in the AgiSoft program.

Ground photos were taken by handheld FLIR T640 camera at previously identified fire location (infrared resolution: 640x480, spectral range: 7.5-14 $\mu \mathrm{m}$ ). Pictures were made immediately after drone raids to obtain the most similar conditions and - at the same time - not interfere with drone flight. Perfect conditions assume taking pictures at an angle as close as possible to the right one. Images have been properly processed in FLIR Tools software to make appropriate corrections resulting from distances to the photographed place, atmospheric temperature, reflected temperature, air humidity, emissivity.

\subsection{Point measurements}

Point pyrometric measurements are another method that allows the monitoring of the object's thermic state. Like thermal images, it is a non-contact temperature measurement method, which makes measurement easier and safer. In addition, many of today's pyrometers have the ability to connect additional thermocouples under it to allow contact measurement at specific depths. This makes research more comprehensive.

Within the identified fire spots, point measurements were made using the RayTemp 28 pyrometer. The device measured the temperature with an accuracy of 0.1 Celsius degree. The pyrometer was additionally equipped with a K-type probe enabling measurements below the surface to a depth of $30 \mathrm{~cm}$. Measurements were made at 24 points on the surface and depth located around the selected fire spot on the coal-waste dump. Points were irregularly distributed. Data interpolation was carried out using ArcGIS software.

\section{RESULTS}

The thermal photos clearly indicate fire phenomena inside the coal-waste dump (Figure 1). The highest obtained surface temperatures on 22.03.2018 reach almost $+50^{\circ} \mathrm{C}$, while the air temperature during the measurement was about $-2^{\circ} \mathrm{C}$ (Figure 1B). A similar situation was observed in October 2018. The highest temperature recorded was about $+55^{\circ} \mathrm{C}$, while the air temperature was $+9^{\circ} \mathrm{C}$ (Figure 1C). Under normal conditions (in areas not affected by fire), the ground temperature should be similar to the air temperature. It also happens for the selected dump and its surroundings. The area that does not burn has a temperature much lower than the fire spots.

Comparing thermal photos with an orthophotomap taken at a similar time using the same drone, the relationship between fire spots and land cover can be obviously seen. Burning places are clearly not covered by any vegetation (Figure 1A).
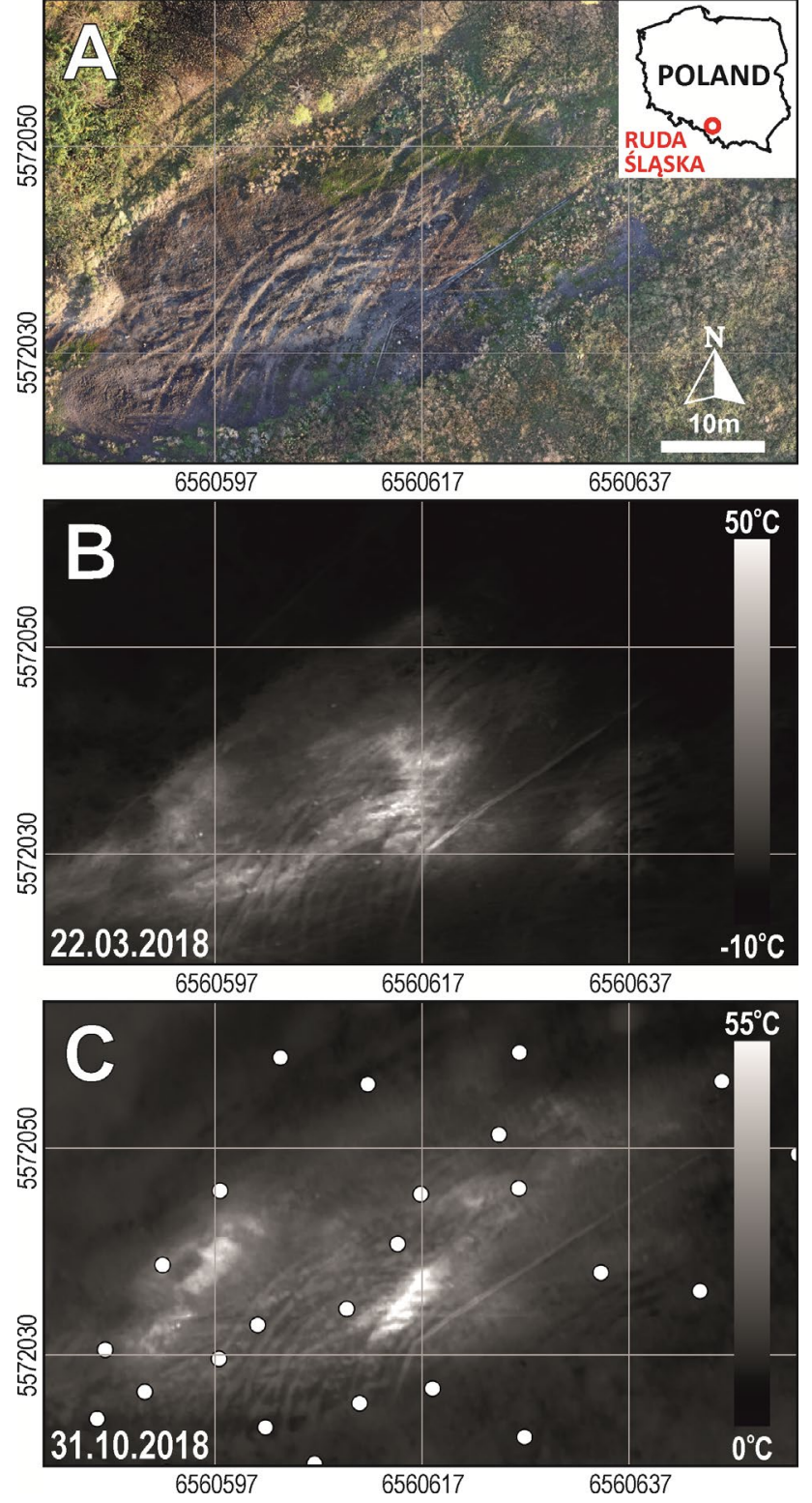

Figure 1. Fire spot on the coal-waste dump in Ruda Śląska: A - orthophotomap; B - thermal map: 22.03.2018; C - thermal map: 31.10.2018 (points - see Figure 3);

coordinate system Poland CS2000 zone 6, EPSG: 2177

$\left(5572050,6560597=\right.$ WGS $\left.84: 50^{\circ} 16^{\prime} 52.57^{\prime \prime} \mathrm{N}, 18^{\circ} 51^{\prime} 0.86^{\prime \prime} \mathrm{E}\right)$

A fire spot registered from the air is also noticeable in thermal photos taken from the ground by the handheld IR camera (Figure 2). Due to the diversity of the ground (it is not perfectly flat), its coverage and the variability of the angle of taking pictures, the fire border is not as well outlined as in the pictures from the drone. These photos may also be subject to an additional error because they were taken during sunrise (at the beginning of the sky brightening), which may cause the influence of the cold sky reflection (Nowak, 2013). However, apart from any errors resulting from terrain restrictions and measurement time, the obtained surface temperatures - as in the case of drone photos - are characterized by high diversity. They clearly show the place of fire with two hot spots, which are clearly visible in the photo from the air (Figure 1C). 


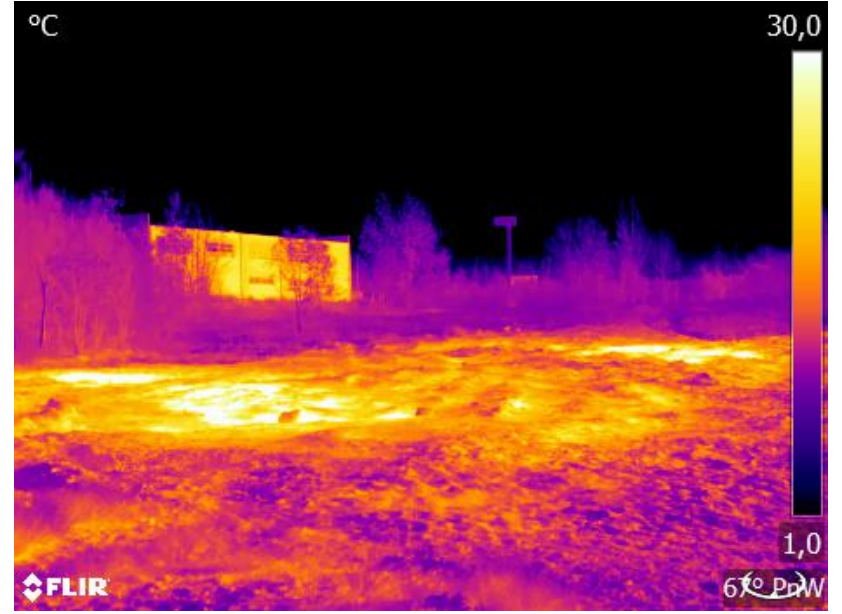

Figure 2. Fire spot photo taken with a handheld IR camera (31.10.2018)

The selected fire spots were also identified during pyrometric measurements. Just like on thermal photos, the fire has an SWNE linear course (Figure 3). The values obtained from surface (Figure 3A) and underground measurements (Figure 3B) differ significantly from each other. Up to a depth of $30 \mathrm{~cm}$ these differences exceed $80^{\circ} \mathrm{C}$. This indicates that the fire processes are well advanced and shows the structure of the fire.
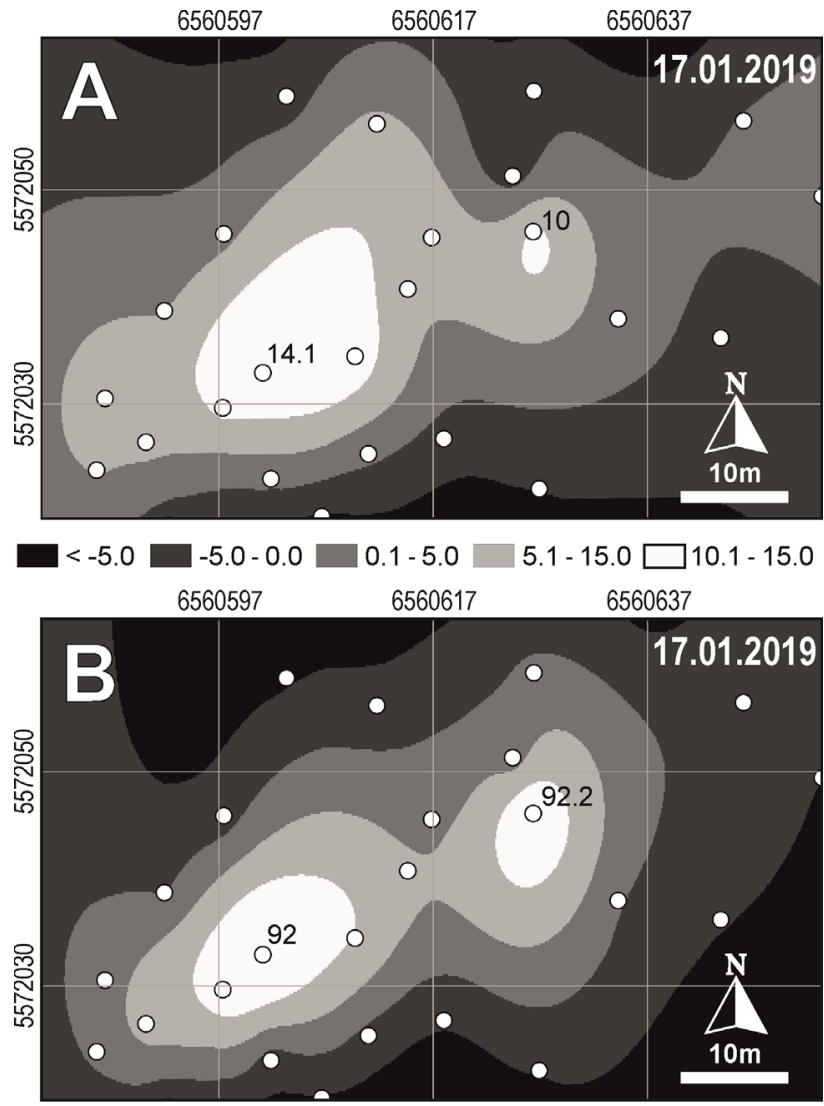

$<0.0 \square 0.0-25.0 \square 25.1-50.0 \square 50.1-75.0 \square 75.1-100.0$
Analyzing the images presented in the figures and treating them as a series of data (Figure 1B, 1C, 3A) the movement of the fire point in the north-east direction can be noticed. Changes in the location of the fire reached about 30 meters per year. The exact course of the firing range was dependent on the measurement method (the differences reach several meters).

The results of the research show the problem of comprehensive measurements of the fire phenomenon. On the one hand, the multiplicity of measurement techniques authenticates and supplements the collected data, but on the other hand, it makes the organization of the measurement much more difficult and longer. Restrictive conditions make complicated to plan reliable measurements (mainly due to weather and time requirements). An additional problem is the dynamics of fires changes in time and space. Prolonging (or slowing down) the measurement process reduces the reliability of the comparative analysis of collected data. It may introduce additional errors in the reconstruction of the fire model. The use of only one data type (point measurements or thermal images), unfortunately, greatly limits the possibilities of proper recognition of the fire phenomenon. It is closely related to the variability of the fire along with the depth (with a complete lack of this variability trend).

\section{CONCLUSION}

Fires are a huge threat to local society. Municipal governments should ensure their proper monitoring to be able to control this phenomenon. Although geo-portals or other spatial information systems are already working in many Polish counties and communes, usually the information collected there relates to land cover or landform. Currently, the only open-access thermal information is satellite data (Nádudvari, 2014; Nádudvari, Ciesielczuk, 2018). Unfortunately, their resolution (e.g. Landsat) is so low that on small objects fires are not identified (their area is much smaller than a pixel size) (Wasilewski, Choroba, 2011; Syed et al., 2018). Supplementing the local databases with thermal data of objects at risk of fire could be quite useful. Such data would transparently inform communes, investors and residents about the state of the environment, but also about ongoing fire processes. The easiest way to do this is to use drones. It is much less timeconsuming. However, if we focus on a more detailed analysis of the process to predict their progress - we should also carry out ground measurements that show the internal situation of the object.

Observation of areas susceptible to fire can provide a lot of important information on the course of this phenomenon. Even without specialized equipment, we can observe on open-access orthophotomap series (e.g. http://www.psip.rudaslaska.pl/imap/) fragments of terrain that differ from the surroundings, including through lack of vegetation (in summer) or lack of snow cover (in winter). A pungent odor or escaping smoke can also lead to fire places. However, much more information is provided by thermal data. Knowing the specific temperature values, it is possible to determine the extent of the fire and its diversity (Huo et al., 2014).

Figure 2. Thermal maps prepared on the basis of pyrometric measurements: A - surface temperature $\left[{ }^{\circ} \mathrm{C}\right]$; $\mathrm{B}$ - the temperature at a depth of $30 \mathrm{~cm}\left[{ }^{\circ} \mathrm{C}\right]$ 
The data from one source seems to be incomplete and will not reflect the actual state of coal-waste dump's fire. To make the monitoring credible, it should be carried out regularly and comprehensively, using both terrestrial and aerial data. It will enable to detect the present changes of the coal-waste dumps' fires. Moreover, the proper monitoring will increase the chance of prediction these fires enough early to combat the threat.

\section{REFERENCES}

Abramowicz A., Chybiorz R., 2017. Coal-waste dumps database of Upper Silesian Coal Basin. 17th International Multidisciplinary Scientific GeoConference SGEM 2017, pp. 425-430.

Drenda J., Różański Z., Słota K., Wrona P., 2007. Zagrożenie pożarowe na zwałowiskach odpadów powęglowych. Górnictwo i Geoinżynieria, Vol. 31, No. 3/1, pp. 149-157.

Gawor Ł., 2014. Coal mining waste dumps as secondary deposits - examples from the Upper Silesian Coal Basin and the Lublin Coal Basin. Geology, Geophysics and Environment, Vol. 40, No. 3, pp. 285-289.

Huo H., Jiang X., Song X., Li Z.-L., Ni Z., Gao C., 2014. Detection of Coal Fire Dynamics and Propagation Direction from Multi-Temporal Nighttime Landsat SWIR and TIR Data: A Case Study on the Rujigou Coalfield, Northwest (NW) China. Remote Sensing, Vol. 6, pp. 1234-1259.

Jonczy I., Gawor Ł., 2017. Coal mining and post-metallurgic dumping grounds and their connections with exploitation of raw materials in the region of Ruda Śląska. Archives of Mining Sciences, Vol. 62, No. 2, pp. 301-311.

Korski J., 2010. Termowizja w monitoringu i zwalczaniu pożarów składowisk odpadów pogórniczych. Górnictwo i Geologia, Vol. 5, No. 2, pp. 91-103.

Łączny J.M., Baran J., Ryszko A., 2012. Opracowanie $i$ wdrażanie innowacyjnych technologii środowiskowych stosowanych nazwałowiskach odpadów powęglowych. Wydawnictwo Naukowe Instytutu Eksploatacji - PIB, p. 300.

Nádudvari Á., 2014. Thermal mapping of self-heating zones on coal waste dumps in Upper Silesia (Poland) - A case study. International Journal of Coal Geology, pp. 47-54.

Nádudvari Á., Ciesielczuk J., 2018. Remote Sensing Techniques for Detecting Self-Heated Hot Spots on Coal Waste Dumps in Upper Silesia, Poland. Coal and Peat Fires: A Global Perspective: Volume 5: Case Studies - Advances in Field and Laboratory Research, pp. 102-119.

Nowak H., 2013. Wpływ oddziaływania cieplnego promieniowania środowiska zewnętrznego na wyniki termowizyjnych badań budynków. Budownictwo i Architektura, Vol. 12, No. 3, pp. 59-66.

Syed T.H., Riyas M.J., Kuenzer C., 2018. Remote sensing of coal fires in India: A review. Earth-Science Reviews, Vol. 187, pp. 338-355.

Wasilewski S., 2009. Zastosowanie nowoczesnych technologii monitoringu $\mathrm{w}$ badaniach aktywności termicznej składowisk odpadów kopalnianych. Przegląd Górniczy, Vol. 65, No. 5-6, pp. 88-92.
Wasilewski S., Choroba T., 2011. Zdalne pomiary temperatury w ocenie aktywności termicznej składowisk odpadów węglowych. Górnictwo i Geoinżynieria, Vol. 35, No. 1, pp. 93106.

Wasilewski S., Korski J., 2010. Early fire detection as a part of mine waste dump monitoring. Mechanizacja i Automatyzacja Górnictwa 8, pp. 3-17. 